\title{
THE SYNTAX OF NOMINALIZED COMPLEX VERBAL PREDICATES IN
}

DAGAARE

Adams Bodomo

\begin{abstract}
Nominalization and verb serialization are widely attested phenomena in the generative linguistic literature, but an in-depth study of their interaction remains to be undertaken. Based on data from Dagaare, a Gur language of West Africa, this paper analyses a type of complex predicate construction, nominalized serial verbs, in which only one of the verbs carries a nominalization affix. With this, a number of issues about the nature of complex predicatehood, syntactic alternations, and lexical categorial differences involving nouns and verbs across languages are addressed. The paper proposes that, basically, serial verb nominalizations are VPs headed by a NomP functional projection.
\end{abstract}

\section{Introduction ${ }^{1}$}

This paper analyses a type of complex predicate construction in Dagaare (a member of the Gur branch of the Niger-Congo language family, spoken in West Africa by about two million people) involving not only verb phrase (VP) phenomena but also noun phrase (NP) phenomena. Specifically, this concerns the nominalization of serial verbal predicates. We term this nominalized serial verbal predicates or even serial verb nominalization (SVN) (Bodomo and Oostendorp 1993). The constructions in (1b) may serve as a first example of the phenomenon. As can be seen, the last of the verbs in the serial verb construction (SVC) in (1a), di 'eat' is nominalized and the object NP à tàn'gmà 'the shea fruits' is preposed. The 
non-trivial effect of these syntactic alternations is that the whole verbal construction is now a nominalized construction. The consequence of this alternation is that the original SVC, headed by a VP, is now headed by an NP or a determiner phrase (DP). The SVN construction is therefore an interface zone for VP and NP phenomena, bringing issues of serialization and nominalization in focus. ${ }^{2}$
a.
déré nà zó gàà dì
dí lá
lá à
tàngmà
Dery FUT run go eat FOC DEF shea fruit.PL
'Dery will go and eat the shea fruits (by running).'

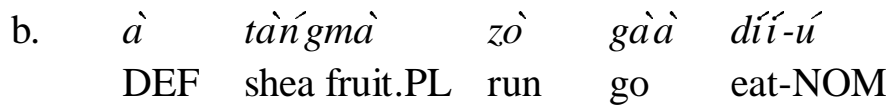
'The run go eating of the shea fruits' i.e.
Running there in order to eat the shea fruits

Even though nominalization and verb serialization are widely attested phenomena in the generative linguistic literature, there exists no known published attempt at accounting for the interaction between the two grammatical phenomena. The Dagaare data presented here can be used to begin a debate on these syntactic and semantic phenomena across languages. With this goal in mind, a greater part of the paper is devoted more to issues of description than to formalization.

The paper will be organized as follows. First, since the SVN partially involves NP phenomena, we give a brief presentation and representation of the facts of the Dagaare NP in section 1, mainly using the DP hypothesis. In section 2, we present the SVN facts, and offer in section 3 a syntactic representation of SVNs in the DP hypothesis, along with Lexical-Functional Grammar (LFG)-type functional structures to capture certain syntactic alternations in the SVN. 


\section{The Structure of the Nominal Phrase in Dagaare}

We begin this section of the paper with a discussion of the basic structure of the Dagaare noun phrase, including information on earlier studies and a brief discussion about some issues of constituency in the noun phrase. The following sentences in (2) and (3) illustrate simple Dagaare noun phrases, along with some basic facts about grammatical categorial markings within the noun phrase in this language.

$$
\begin{aligned}
& \text { a. à gánè é lá béróng } \\
& \text { DEF book.SG be FOC fat } \\
& \text { 'The book is fat.' }
\end{aligned}
$$

(3) a. ǹ dà dé lá áyúó bié gánè

1.SG PAST take FOC Ayuo child book.SG

'I took Ayuo's child's book.'

b. áyúó bié gánè é lá gán-vílàa yágà

Ayuo child book.SG be FOC book-good INTENS

'Ayuo's child's book is a very good one.'

As can be seen in (2), the grammatical categories, number and definiteness, are overtly marked and distinguished within the Dagaare noun phrase. The noun, gánè 'book', alternates between a singular and a plural form. Also, the definite form of this same noun is preceded by the definite marker, $\grave{a}$, while its indefinite form does not have any such item preceding it.

Case and gender, on the other hand, do not have overt markings within the Dagaare lexical noun phrase. This is illustrated in (3), where there is no morphological difference in the nominative/subjective and accusative/objective occurrences of the noun phrase, Áyúo 
bié gánè 'Ayuo's child's book'. Gender, as mentioned, is also not overtly marked, as there is no morphological difference between the nominative and genitive uses of the first person pronoun, $\grave{n}$, in Dagaare. Earlier studies of the nominal phrase in Dagaare and related languages give us more substantial facts for understanding the nature of noun phrases and nominalization in Dagaare.

\subsection{Earlier Studies}

Earlier studies of the Dagaare noun phrase include Angkaaraba (1980), Bodomo (1993), Bodomo and Oostendorp (1993) and Bendor-Samuel (1971). The last is a study of general Gur NP, Gur being the group of languages Dagaare and other Mabia languages belong to.

a) Angkaaraba (1980):

Whereas Bendor-Samuel (1971) claims a very simple NP structure for Gur languages, including Dagaare, for example suggesting that only one adjective could follow a head noun, the much richer possible structure of Dagaare NPs was clearly laid out in Angkaaraba (1980). The diagram below shows the complexity of the Dagaare noun phrase, according to Angkaaraba (1980):

(4)

\begin{tabular}{|l|l|l|l|l|l|l|l|l|l|}
\hline 6 & 4 & 2 & 0 & 1 & 2 & & & & 3 \\
\hline & & & & & .2 & .4 & .6 & .8 & \\
\hline Art & $\mathrm{np}$ & $\mathrm{nm}$ & $\mathrm{NH}$ & (pl) & Adj & Adj & Adj & Adj & (pl) \\
\hline
\end{tabular}




\begin{tabular}{|l|l|l|l|l|l|}
\hline 4 & 6 & 7 & 8 & & 10 \\
\hline & & & .2 & .4 & \\
\hline Q & D & (pl) & int & int & loc \\
\hline
\end{tabular}

Key: Art - Article; np - nominal phrase; nm- noun modifier; NH; Noun Head; pl - plural; Adj - Adjective; Q - Quantifier; D Demonstrative; int - intensifier; loc - locative. Even numbers show slots where major constituents of the nominal phrase occur, while odd numbers indicate affixes of the preceding item.

According to the diagram, the head noun can be followed by adjectives, quantifiers, demonstratives, intensifiers, and locative markers. On the other hand, it can be preceded by modifiers, another noun phrase, and articles. Indeed, contrary to Bendor-Samuel (1971) which claims that Gur languages never exhibit a string of adjectives after the head noun, this actually happens in Dagaare according to Angkaaraba (1980). The following construction illustrates this and all the other structures in the diagram:

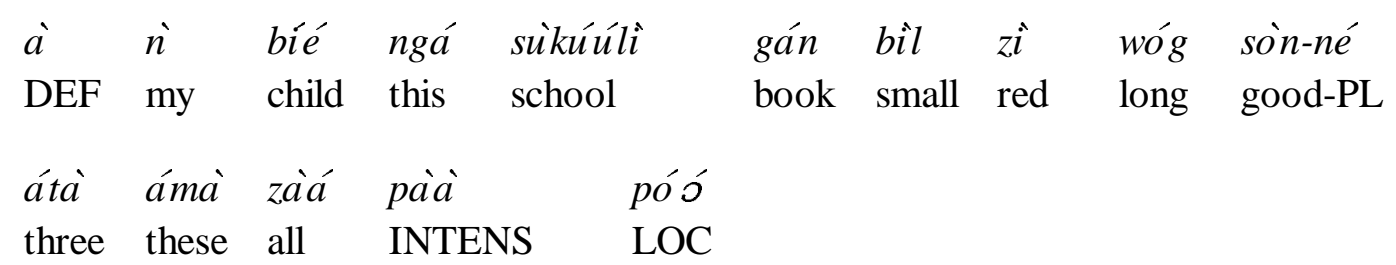

'Among all these three small red long good school books of this my child'

'Gán' is the head noun. It is followed by as many as four adjectives. ${ }^{3}$

b) Bodomo (1993):

This study builds on Angkaaraba (1980). While Angkaaraba (1980) sets only a maximum of four adjectives to follow the head, we can have more adjectives than that, as shown below.
à
gán bil zi
wóg bàil sòn-né
ná
DEF book small red long slendergood-PL those
'Those small, red, long, slender, good books' 
Of course, the argument about whether strings of adjectives can or can never follow a noun head in Gur is partly also an argument about whether we consider nouns and adjectives to form one or more than one word. This issue may be clarified when we look at the following data in (7) and (8) from Dagaare and Mampruli (another Gur language) respectively.

Dagaare:

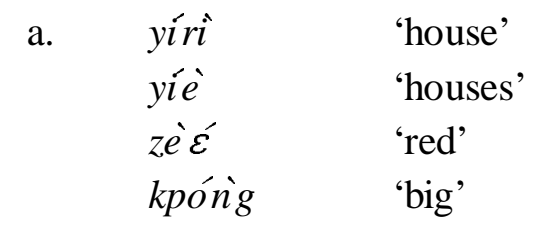

but

$$
\begin{aligned}
& \text { b. } \quad y \dot{i}-z \grave{e} \varepsilon \\
& \text { house-red } \\
& \text { 'red house' } \\
& y i ́-z \grave{e} e ̀-r e ́ \\
& \text { house-red-PL } \\
& \text { 'red houses' } \\
& \text { yí-zè-kpón'g } \\
& \text { house-red-big } \\
& \text { 'red big house' } \\
& \text { yí-zi-kpón-ni } \\
& \text { house-red-big-PL } \\
& \text { 'red big houses' }
\end{aligned}
$$

Mampruli:

$\begin{array}{lll}\text { (8) a. } & \text { gbangngu } & \text { 'book' } \\ & \text { bila } & \text { 'small' } \\ & \text { gyia } & \text { 'red' }\end{array}$


but

b. gbang-bili-gyea

book-small-red

'small red book'

gbang-bili-gyee-se

book-small-red-PL

'small red books'

In both Dagaare and Mampruli, as can be seen from the data, only the root of the noun is available when the noun takes on one or more adjectives.

Indeed adjectives also lose part of their endings when they combine with a following adjective. The noun and adjective(s) can be seen as forming one word. This observation is buttressed by the fact that the plural of the whole complex appears at the end of the last adjective.

Looking at these constructions in Dagaare and Mampruli as single words would probably be the only way to defend the claim made by Bendor-Samuel (1971) that a noun (word) is never followed by a string of adjectives (as separate words) in Gur. Even then the data do not dispute the fact that a noun or its stem is followed by adjectives or adjectival stems.

c. Bodomo and Oostendorp (1993):

This study went further to show more complexities of the nominal phrase in terms of processes such as serial verb nominalization. Besides the descriptive advances, the study gave a formalization of the nominal phrase structure within the DP hypothesis of the GB grammatical framework. 
The noun phrase has traditionally been described as that part of the sentence headed by the noun or pronoun. However, there are analyses within the linguistic literature (e.g. Hellan 1986, Abney 1987) that have challenged this conventional wisdom, arguing that the noun phrase is headed by the determiner, in which case then one would talk of the Determiner Phrase (DP). In this work we do not undertake an evaluation of which of the two approaches is better suited for nominal phrase formalization; we simply attempt to show how the DP approach can represent SVNs.

Abney (1987) argues that the determiner within the noun phrase should be analyzed as a functional head like other functional or non-lexical items such as INFL and COMP. In the same way that we have IP and CP in many languages of the world it is rational to have a DP cross-linguistically, according to this hypothesis. The DP is assumed to contain elements like determiners, demonstratives, and quantifiers. The Quantifier Phrase (QP) contains elements like numerals and other quantifier heads or phrases, as shown in (9).

(9)

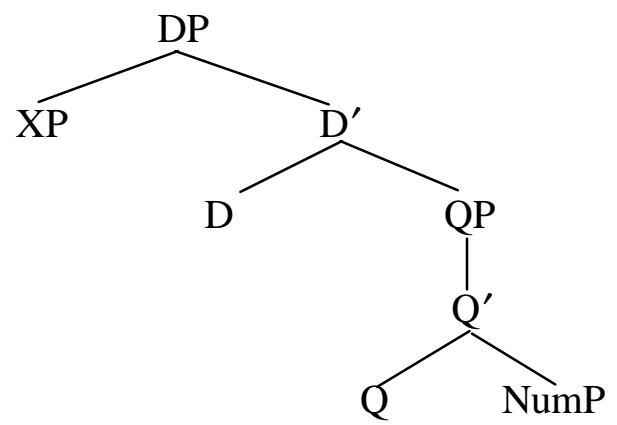

Now look at the Dagaare DPs in (10):

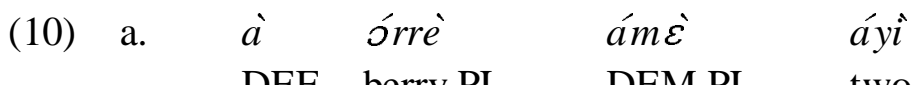

DEF berry.PL DEM.PL two

'These two berries' 
b. báyúógán bìl- zî- wóg- bàil- sòn-né áyi Bayuo book small red long slender good-PL two 'Bayuo's two small, red, long, slender, good books'

Apart from the determiner, $\grave{a}$, and possessive phrases, all elements in these phrases follow the head noun. Tentatively, we may conclude that this means that, except for DP, all projections in the Dagaare nominal phrase are head final. We thus get the structures in (11a) and (11b) for (10a) and (10b) respectively (some of the irrelevant intermediary structure is omitted): ${ }^{4}$

(11) a.

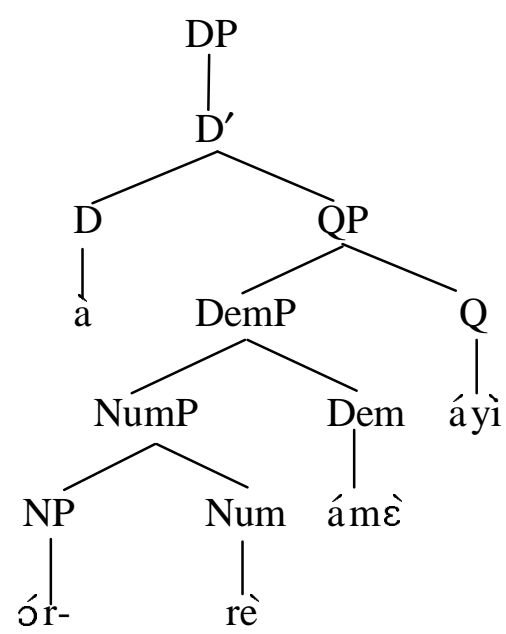


b.

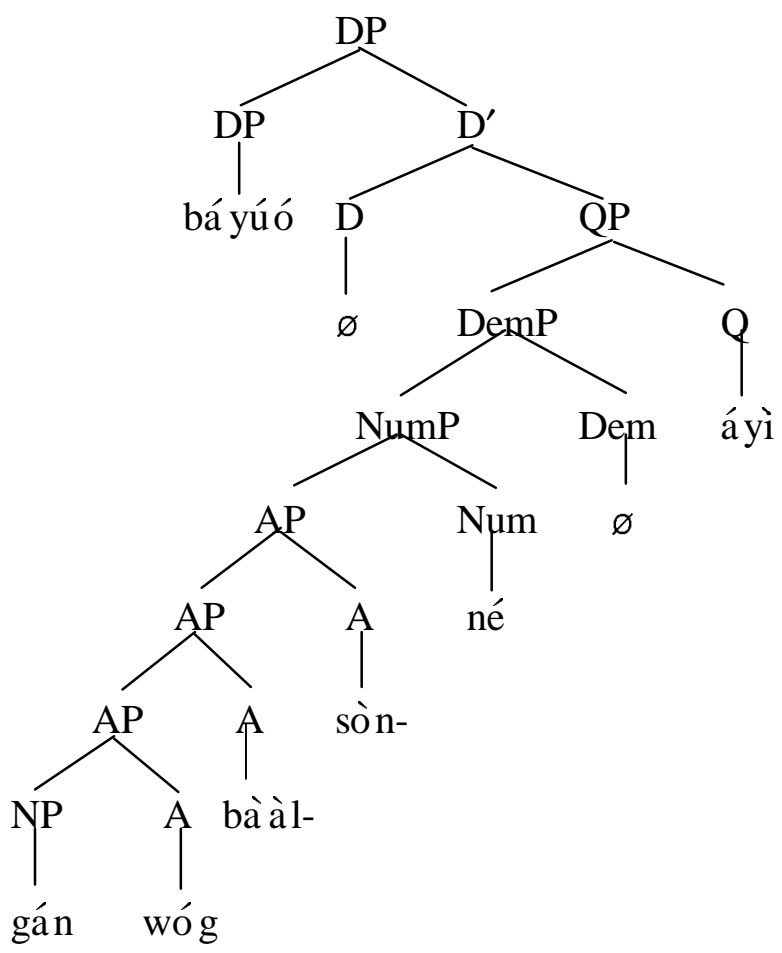

c.

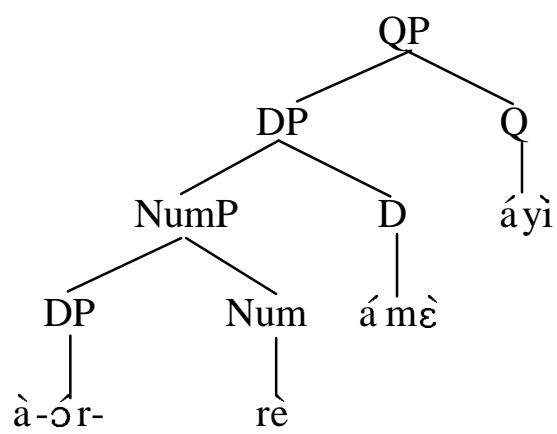

In these structures, the demonstratives and determiners have been given their own projections. This is not a matter of necessity. We could also assume a structure as in (11c $)^{5}$. In this structure all nominal functional projections are right-headed. The determiner $a$ ' behaves as a clitic, coindexed with $\mathrm{D}^{0}{ }^{6}$ 
Having now given a survey of earlier treatments of the Dagaare nominal phrase and a short representation of this with the DP analysis, we shall in the next subsection state the facts of nominalization in Dagaare.

\section{2. Nominalization in Dagaare}

Nominalization is a process which involves the formation of nouns from verbs and adjectives. The following table shows how a number of verbs and adjectives are nominalized in Dagaare:

a. Verb

\begin{tabular}{|c|c|c|}
\hline$z o^{\circ}$ & 'run' & zóóú/zóóbú \\
\hline$w a `$ & 'come' & wááól wáábó \\
\hline to & 'touch' & tóóó/tó óbó \\
\hline$n g m \grave{\varepsilon}$ & 'beat' & ngmé ع́bó/ngmé ع́bó \\
\hline$\dot{\varepsilon}$ & 'swoop' & 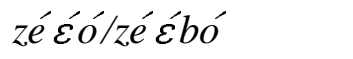 \\
\hline$b \grave{e}$ & 'grind roughly' & gbiébú \\
\hline & 'go' & gááó/gáábó \\
\hline خ' & 'darken' & sóóo/s ó óbò \\
\hline
\end{tabular}

b. Adjective

\begin{tabular}{|c|c|c|}
\hline fáá & 'bad' & fàilóng \\
\hline vèläà & 'good' & vè Èlòng \\
\hline pèlàá & 'while' & pèc่lòng \\
\hline kpónig & 'big' & kpónnúng \\
\hline wógi & 'long, tall' & wógrúng \\
\hline sógláá & 'black, dark' & sòglóng \\
\hline ngmáá & 'short' & ngmàilóng \\
\hline
\end{tabular}

Nominalized item 'the act of running' 'the act of coming, arrival' 'the act of touching' 'beating' 'the act of swooping' 'grinding roughly' 'going/departure' 'darkening' 
Nominalization rules:

The following are examples of morpho-phonological derivational (i.e. word class changing) rules in Dagaare. These rules, stated rather informally, operate on a word to form another which belongs to a different word class:

$$
\text { Verb }+\mathrm{V}(\mathrm{C}) \mathrm{U} \longrightarrow \text { Noun }
$$

(A V (standing for any vowel) may be lengthened or diphthongized; if the vowel of the verb is already long or diphthongized, no further lengthening or diphthongization is required; U (standing for high, back vowel) is unspecified for Advanced Tongue Root (ATR): it takes the ATR of the source word)

$$
\text { Adjective + LUN } \longrightarrow \text { Noun }
$$

( $\mathrm{L}$ is meant to be any liquid but note that if the adjective ends in a nasal the derivation involves a nasal gemination rather than L. Again $U$ is unspecified for ATR: it takes the ATR of vocalic items in the source word.)

With these data and rules showing how verbs and adjectives are nominalized, ${ }^{7}$ we now state the facts of nominalizing the simple VP in Dagaare to give us more extended NPs. A verb like $d i i^{\prime}$ eat' can be nominalized by marking it with the ending $-(i) u$. If it appears, the direct object stands to the left of the head in these constructions. Compare (15a) to (15b), for example.
a. báyòo di-ré lá à tàngmà
Bayor eat-IMP FOC DEF shea fruit.PL
'Bayor is eating the shea fruits.'
b. à tàngmà dí-íú wá báárè
DEF shea fruit.PL eat-NOM NEG finish.PERF
'The eating of the shea fruits is not finished.'


The construction in $(15 b)$ is introduced by the definite article $a$. Instead of this, we could also have an NP in the position of this determiner (16a). This NP would then denote the agent of the action. Finally, the position can also be left empty, as in (16b).
a. báyúó tànǵmà
dí-íú

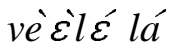
Bayuo shea fruit.PL eat-NOM good FOC
'Bayuo's eating of shea fruits is good.'
b. tànǵmà dí-íú nòmó lá
shea fruit.PL eat-NOM sweet FOC
'Eating shea fruits is nice.'

báyúó in this position could be a genitive or it could be a nominative. We cannot tell because the language lacks overt case marking (cf. (17)):

$$
\begin{aligned}
& \text { báyúó gánè wá vè घ̇lé } \\
& \text { Bayuo book.SG NEG } \\
& \text { 'Bayuo's book is not good.' }
\end{aligned}
$$

The direct object that is now nominalized and brought to the beginning can be a bare noun like in (16b), but it can also be an NP of more complexity (18b and c):

$$
\begin{aligned}
& \text { a. órà dí-íú nòmó lá } \\
& \text { berry eat-NOM sweet FOC } \\
& \text { 'Eating a berry is nice.' }
\end{aligned}
$$
b. à jờà nyè dí-íú nòmó lá
DEF berry DEM.SG eat-NOM sweet FOC

'The eating of this berry is nice.'

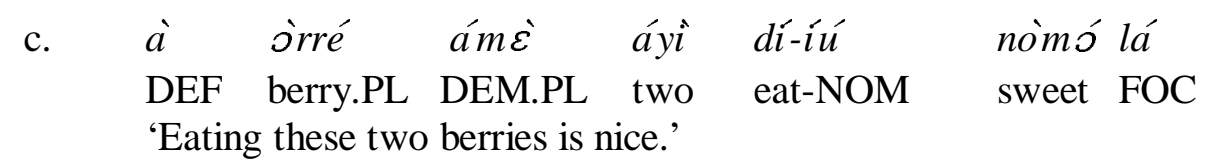


The resulting structure can be modified by an adjective - which is incorporated into the head as in (19a) or by an adverb as in (19b). The variant with the adverb is far more common, however.

a. à tànǵmà di-vèżlòng

DEF shea fruit.PL eat-good/nice

'The good eating of the shea fruits' i.e.

'The nice way of eating the shea fruits'

b. à tànǵmà vèlàà dí-iú

DEF shea fruit.PL good eat-NOM

'The good eating of the shea fruits' i.e.

'The nice way of eating the shea fruits'

These are then some of the facts of nominalizing the simple VP in Dagaare. In the next section we shall focus on the more complex case of nominalizing serial verbal predicates.

\section{The Facts of Serial Verb Nominalization}

In nominalizing serial verb constructions in Dagaare, the last of the series of verbs gets the nominalized suffix. If there is a direct object to the last verb, it can only occur at the outer left of the verbal cluster:

$$
\begin{array}{llll}
a & n \mathcal{E}^{\prime} & d o ́ g & \text { óó-ó } \\
\mathrm{DEF} & \text { meat } & \text { boil } & \text { chew-NOM }
\end{array}
$$

'The cook chewing of the meat' i.e.

'The cooking of the meat in order to eat'

(21) a. à tànǵmà zò gàà dí-iú

DEF shea fruit.PL run go eat-NOM

'The run go eating of the shea fruits' i.e.

'Running there in order to eat the shea fruits'

b. * à zò gàà tànǵmà díú

c. * à zò tànǵmà gàà díiú 
Not just the direct object NP, but also other constituents appear obligatorily to the left of the verbal cluster. This is the case with adverbials such as wiéwié 'quickly' as can be seen in

a. à tànǵmà wiéwié zò gåà dí-íú

DEF shea fruit.PL quickly run go eat-NOM

'The run go eating of the shea fruits quickly' i.e.

'Running there quickly in order to eat the shea fruits'

b. *à wiéwié zò gàà tànǵmà diưú

c. * à wiéwié zò tànǵmà gåà díúú

It seems that for one reason or another, the verbs have to be obligatorily adjacent in these constructions. This is a first indication by the facts of SVN in support of a theoretical analysis of serial verb constructions as complex predicates, undergoing syntactic operations as a single unit. ${ }^{8}$ It is impossible to use the imperfective aspect in these constructions; they all seem to be in the perfective aspect or lack aspectual marking altogether:
a. *à tànǵmà
$z \grave{o}-r o ́ \quad g \grave{\varepsilon}-r \mathcal{E}$
dí-íú
DEF shea fruit.PL
run-IMP go-IMP
eat-NOM
b. *à nén dúg-rò
óó-ó
DEF meat boil-IMP
chew-NOM

Perhaps we can conclude that the nominalized form is inherently in the perfective aspect or that, since the whole construction is now nominal, aspect is not even marked at all. Tense also cannot be expressed in nominalized constructions. Compare the sentences in (24) with the nominalized constructions in (25):
a. à bié ná zó
gà
$d i$
lá á
à tànǵmà
DEF child FUT run go eat FOC DEF shea fruit.PL

'The child will run there (and) eat the shea fruits.' 
b. à bié dà zó gàà dí lá à tànǵmà DEF child PAST run go eat FOC DEF shea fruit.PL 'The child has run there and eaten the shea fruits.'

(25)
a. *à tànǵmà ná zó gàà dí-íú
DEF shea fruits FUT run go eat-NOM
b. *à tànǵmà dà zó gàà dí-iú
DEF shea fruits PAST run go eat-NOM

\subsection{Types of SVCs and their nominalized counterparts}

As a further documentation of the facts of SVNs, I show in this section that not all SVC types have nominalized counterparts ${ }^{9}$. This will be illustrated with four main SVC types in the language: instrumental, benefactive, inceptive, and causative serialization, as outlined in Bodomo (1997).

\subsubsection{Instrumental serialization}

Another characteristic feature of these SVN constructions is that it is difficult to get an acceptable reading when two NP objects are involved. This is the case with instrumental SVCs. An example of instrumental serialization is provided in (26a).
a. ò dà dé lá sòó ngmåà nźñ òò
3.SG PAST take FOC knife cut meat chew
'S/he cut meat with a knife and ate it.'

b. ?à néñ à sòó dé ngmåà óó-ó

DEF meat DEF knife take cut chew-NOM
c. ?? à nén dé à sòó ngmåà óó-ó
DEF meat take DEF knife cut chew-NOM

d. *à sòó dé nén ngmãà óó-ó

DEF knife take meat cut chew-NOM 
As can be seen in (26b-d) there are acceptability problems when we try to nominalize the SVC in (26a). Besides the author's speaker intuitions, these constructions were discussed at length on various occasions with four other native speakers (two men and two women). All five agreed on (26d) as ungrammatical, while we were divided about the grammaticality status of (26b and c). The construction in (26b) was generally said to be better than (26c) but the general agreement was that both (26b and c) are quirky and do not look like natural Dagaare sentences. We may therefore speculate at this point that SVN is more naturally derived from the typical object-sharing type of serial verb constructions, usually involving just two verbs and one object occurrence. It is probably no sheer coincidence that it is these types of SVCs which seem to behave more as a unit under various syntactic alternations.

\subsubsection{Causative serialization}

This type usually involves causation of some sort but there are different ways in which causation is expressed from language to language. In Dagaare it involves an inherently causative verb expressed subsequent to the activity verb engendering the causation. This is illustrated in (27a), with (27b) as the nominalized counterpart.

$$
\begin{aligned}
& \begin{array}{lllll}
\text { a. } & \text { ò } & \text { dáá } & \text { má } & \text { lá ló } \\
& \text { 3.SG } & \text { push } & \text { 1.SG.ACC } & \text { PART cause.fall }
\end{array} \\
& \text { 'S/he pushed me down.' } \\
& \text { b. } \quad \grave{a} \grave{n} \text { dáá lóśò } \\
& \text { DEF 1.SG.NOM push cause.fall-NOM } \\
& \text { 'The pushing down of me' = 'My having been pushed down' }
\end{aligned}
$$

Not all serializing languages express causation as in the Dagaare case above. Some like Twi (which belongs to the Kwa subgroup of the Niger-Congo language family) express it by the 
so-called switch subject serialization, an SVC whose object of the first verb and subject of the second verb are co-referential (Osam 1994).

a.

$$
\grave{j}
$$$$
m \grave{a}-\grave{a}
$$$$
m e ́ \quad w e ́-e ̀ ~
$$$$
\text { ìsá páá }
$$$$
\text { 3SG make-PAST 1.SG chew-PAST drink INTENS }
$$

'S/he made me drink a lot.'

b.

$\begin{array}{llc}m a ́-a ́ & \grave{s}-m a ́- & a ́ \\ \text { Make-EMPH } & \text { 3.SG-make-PAST }\end{array}$

'His making me drink a lot'

c. wé-á

$$
\text { j-máá-á }
$$

mé wé-è

$m e ́$ wé-è

$\grave{n} s a ́$

Chew-EMPH 3.SG-make-PAST

1.SG

'The drinking that he made me drink a lot'

1.SG chew-PAST drink

First, such construction types as seen in Twi do not exist in Dagaare as serial verb constructions, but as biclausal complementation constructions involving the structure: makeCOMP-some event happen and therefore do not fall within the aegis of verb serialization. Second, these structures in Twi do not have nominalized counterparts in the way that the nominalization is deployed in Dagaare. Indeed, Twi serial verbs, as a whole, do not exhibit nominalization in the way that it is done in Dagaare but rather as a kind of focus or emphasis marking construction in which the verb that is emphasized is brought to the fore and emphasized or stressed, as shown in (28b) and (28c) above.

\subsubsection{Benefactive serialization}

Benefactive serialization involves two objects. Usually, a benefactive verb such as 'give' or 'receive' is preceded by an activity verb which creates the object or substance of giving or receiving. 
a. j̀ dà wùó lá hááné kó fó

3.SG PAST collect FOC berry.PL give 2.SG

'S/he collected berries for you.'

b. à fò hááné wùò kó-ó

DEF 2.SG berry.PL collect give-NOM

'Collecting the berries for you'

Benefactive serialization therefore is one of the SVC types that is productive in the phenomenon of creating nominalized counterparts.

\subsubsection{Inceptive serialization}

This type of SVC involves a verb 'take' preceding any activity verb. The verb 'take' does not indeed represent the semantics of grabing or moving something from some location to another. It rather marks the time or point of beginning and initiating something. Unlike the benefactive or instrumental construction this does not always have to have an object.

a. ò nà dé lá à tómá bàrè 3.SG FUT take FOC DEF work leave 'S/he will stop the work/stop working.'

b. à ò tómá dé bár-ó

DEF 3.SG work take leave-NOM

'His/her leaving/stopping the work'

(31) a. tè nàng dà dé gèré ná 1.PL as PAST take go.IMP PART 'As we began to go'

b. à tè dé gáá-ó

DEF 1.PL take go-NOM

'Our beginning to go' $/$ 'the fact of our beginning to move'

As can be seen, both types of inceptive serialization involving object and no object are amenable to the process of nominalization as shown in (30b) and (31b). 
The above survey of a typology of serial verbs involving object sharing and other issues illustrates that, with the exception of instrumental serialization, the phenomenon of SVNs is quite productive in most of the SVCs in Dagaare.

\section{A Syntactic Representation for Serial Verb Nominalization}

Having documented SVN facts in the last section, we now turn our attention to a brief syntactic representation and analysis of these facts in Lexical-Functional Grammar (LFG)-type functional structures and phrase structures. Recent versions of LFG show clearly that this grammatical framework belongs to a family of formal grammars that are increasingly developing a grammatical architecture of parallel structures in correspondence (Sadock 1991, Jackendoff 1997, Bodomo 1997, Bresnan 2001, Falk 2001, and Dalrymple 2001), where rather than one level of representation being derived from another, all levels are independent of each other but only interface through rules of correspondence.

This alternative architecture of grammar is based on parallel structures, three of which include a-(rgument) structure, f-(unctional) structure and c-(onstituent) structure. These belong to the syntactic component and so far are the most developed. These are illustrated below in (32):

a. a-structure:

$$
\begin{aligned}
& \mathrm{R}<\mathrm{q} 1 \ldots \ldots \ldots \mathrm{qn}> \\
& {[\mathrm{f} 1] \ldots \ldots \ldots[\mathrm{fn}]} \\
& {\left[\begin{array}{ll}
\text { PRED } & {[\cdots]} \\
\text { SUBJ } & {[\cdots]} \\
\text { OBJ } & {[\cdots]}
\end{array}\right]}
\end{aligned}
$$

b. f-structure: 
c. c-structure:

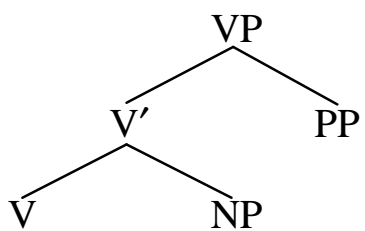

Bresnan (2001:20) explains these levels of representation as follows:

"Each structure models a different dimension of grammatical substance: role, function, and category. Roles correspond to the grammatically expressible participants of eventualities (modelled by a-structure), syntactic functions belong to the abstract system of relators of roles to expressions (modelled by f-structure), and phrase structure categories belong to the overt structure of forms of expression (modelled by cstructure). The structures are associated by principles of functional correspondence (also called "linking" or "mapping" principles)."

The relevant levels as far as the present paper is concerned are the f-structure and the cstructure, and it is SVN representations at these levels that we briefly illustrate in the next sub-sections.

\section{1. Functional Structure of SVNS}

Here, we provide LFG-type f-structure representations of this type of phenomena. ${ }^{10}$ The construction in (33) is an example of SVN to illustrate the various f-structure phenomena of this type of construction.

a. à tànǵmà zò gåà dí-íú

DEF shea fruit.PL go run eat-NOM

'The run go eating of the shea fruits' i.e.

'Running there in order to eat the shea fruits'

b. $\quad\left[\begin{array}{lc}\text { PRED } & \text { 'zò-gàa'díiú }\langle(\uparrow S U B J)> \\ \text { SUBJ } & {[\mathrm{PRED} \text { 'à tànǵma' }]}\end{array}\right]$ 
The f-structure in (33b) is a straightforward representation of SVN. As can be seen, the three verbs, zo' 'run' ga'a' 'go' and the nominalized form of di 'eat' - díiú 'eating' together form a complex predicate ${ }^{11}$, PRED, which is now monadic, as shown by the one argument slot (detransitivization seems to occur with nominalization). This is filled by the SUBJECT functional argument.

Evidence that the NP à tàng'mà 'the shea fruits' becomes the subject of the whole nominalized construction can be adduced from pronominalization in the language. Even though we observed in (2) and (3) above that lexical NPs in Dagaare do not mark case, this does happen with the first person singular pronominal argument in Dagaare. The first person object/accusative pronoun of a normal SVC, which gets nominalized into an SVN, takes the form of nominative/subjective pronoun at the outer left of the whole construction. This is evidence for the fact that the lexical NP of SVCs which get nominalized becomes the subject of the whole nominalized construction. We will illustrate this argument with the following sentences in (34).
a.
báyúó dà zò

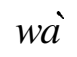
ngmé má
lá
Bayuo PAST run
come beat
1.SG.OBJ
FOC
'Bayuo ran here and beat me.'

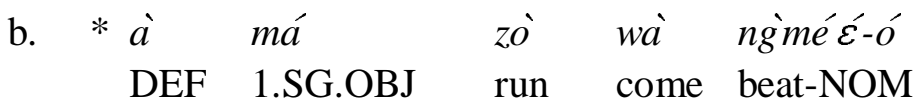
'Bayuo's coming here to beat me.'

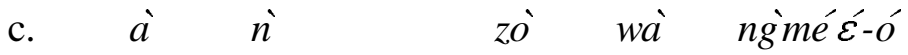
DEF 1.SG.SUBJ run come beat-NOM
'Bayuo's coming here to beat me'
Lit: 'The run coming here to beat me'


The construction in (34b) is ungrammatical because the pronoun contains an objective pronoun case form, má 'me'. However, when its subject pronoun case form, $n$ ' 'I', 'my', is used in this position, as is the case in (34c), the sentence is grammatical. ${ }^{12}$ It seems then that the alternation involving argument NPs in nominalized complex verbal predicates in Dagaare is one of object - subject alternation. ${ }^{13}$

There seem to be only slight differences between the f-structure of nominalized serial verbal constructions and their purely verbal counterparts. This is illustrated in (35).

a. báyúó då zó gåà dí lá à tànǵmà Bayuo PAST run go eat FOC DEF shea fruit.PL 'Bayuo went and ate shea fruits by running.'

b.

$\left[\begin{array}{ll}\text { PRED } & \text { 'zò-gàa-dí<(个SUBJ })(\uparrow \mathrm{OBJ})> \\ \text { SUBJ } & {[\mathrm{PRED} \text { 'báyúo' }]} \\ \text { OBJ } & {[\mathrm{PRED} \text { 'à tàng'ma'] }} \\ \text { TENSE } & \text { PAST }\end{array}\right]$

c. báyúó tànǵmà zò gàà dí-iú

Bayuo shea fruit.PL run go eat-NOM

'The run go eating of the shea fruits by Bayuo' or

'The run go eating of Bayuo's shea fruits by someone else'

d.

\begin{tabular}{|c|c|}
\hline PRED & 'zò-gàa'dííú<( $\uparrow \mathrm{SUBJ})(\uparrow \mathrm{OBJ})>$ ' \\
\hline SUBJ & [PRED 'báyúo' ] \\
\hline OBJ & [PRED 'à tànǵme \\
\hline ENSE & PAST \\
\hline
\end{tabular}

e.

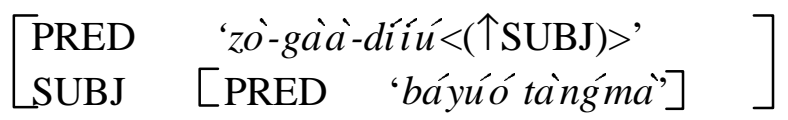

The construction in (35c) is a nominalized version of the SVC in (35a). This SVN is ambiguous, having two readings depending on whether Bayuo is seen as being agentive or simply a possessor. As observed above in several places, such as the examples in (2) and (3), 
Dagaare lacks case marking on lexical nouns, thereby making it impossible to read off a nominal or genitive case. This ambiguity is easily represented with the different f-structures in (35d and e) with báyúó being an agentive SUBJECT on its own in the former and a genitive within the SUBJECT in the latter.

\section{2. Phrase Structure Representation: A DP Analysis of SVNs}

Having discussed the f-structure representation of SVNs in the foregoing subsection, we now focus on a representation of these phenomena at the c-structure level of our parallel grammatical architecture. In terms of X-bar phenomena we shall attempt to extend the DP approach introduced in section 1 to the representation of SVNs.

We now turn back to the nominalization facts. We have already seen that the nominalized forms can be modified by an attributive adjective as well. We assume a nominalization is a VP with a nominal functional projection set on top of it. Some of these functional heads are never realized for semantic reasons. For instance, because nominalizations cannot occur in the plural (cf (36a) for English and (37b) for Dagaare) we also cannot quantify them (cf (36b) for English and (37c) for Dagaare).

(36) a. * Johns readings these books

b. $\quad *$ after three readings these books
a. déré gámà ámè sór-ờ
Dery book.PL DEM.PL read-NOM
'Dery's reading of these books'
b. * déré gámà ámè sór-rè
Dery book.PL these reading-PL
c. *à gá-mà ámè sór-rè átà
DEF book-PL DEM.PL reading-PL three


Focusing now on nominalization, Abney (1987) has proposed that English nominalization constructions have the following structure:

(38)

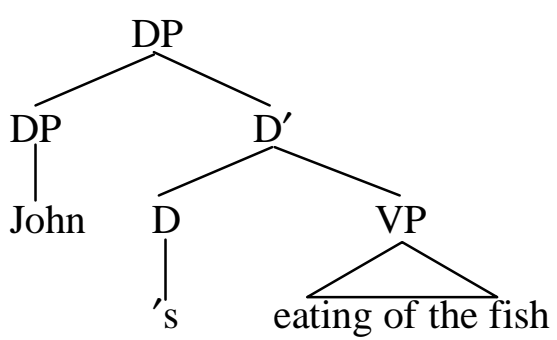

In this view, the nominal gerund constitutes a determiner which exceptionally takes a verbal projection as its complement, instead of a nominal projection. Following this proposal and Bodomo and Oostendorp (1993), we assume that an SVN is a VP with a nominal functional projection set on top of it. This is shown in (34).

a. à tànǵmà zò gåà dí-íú

DEF shea fruit.PL go run eat-NOM

'The run go eating of the shea fruits' i.e.

'Running there in order to eat the shea fruits'

b.

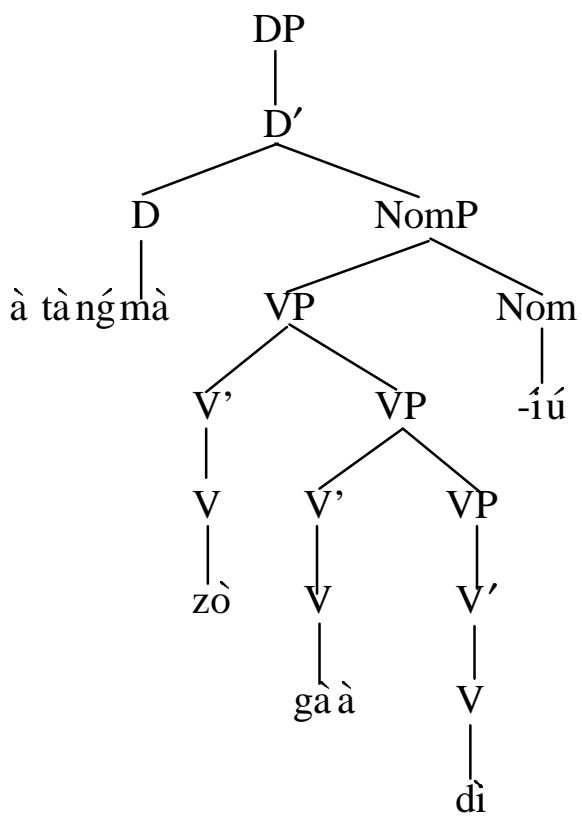


As may be seen in this diagram, we represent SVCs as a succession of VPs with each subsequent VP adjoined to the other. This is different from the object sharing structures in Baker (1989) where an object in the SVC may stand as a complement of two lexical Vs. The obvious question would then be how objects are expressed in this configuration. This is an issue that has been discussed as length in Bodomo (1993, 1997). In this kind of configuration, as indeed in many of Baker (1989)'s configurations, objecthood does not always need to be expressed configurationally as the sister of $\mathrm{V}$ (ie, as a co-constituent of the VP). Basically, the idea of expressing objecthood in such a configuration is to say that objects of the first $\mathrm{V}$ are expressed as sisters of $\mathrm{V}$ but that objects of subsequent Vs are expressed as referring back to the objects of the first V. If an NP occurs as a sister of a subsequent $\mathrm{V}$ and is not co-referential with the object of the first $\mathrm{V}$, the sentence would be ungrammatical.

With this representation we can now predict/explain quite a number of issues concerning the syntax of SVN such as why there is no tense, aspect or other functional categories normally associated with VP. To license the presence of tense for instance, there must be a TP (tense projection). But TP is normally located outside of the VP. However, as can be seen in the above diagram, the NomP projects on top of VP, i.e. where a TP would have been. Assuming that NomP and TP cannot occur together, there is thus no position for TP outside of the VP. The NP, à tàng'ma', can now also alternate to the beginning of the nominal complex (leaving the verbs adjacent to each other) since it is the subject of the whole construction. Evidence that it is the subject of the construction has already been adduced with the facts of the syntactic alternation involving pronouns in (34). 
We now bring this representation of the syntax of nominalized complex verbal construction in Dagaare to a close by drawing attention to one of the many possible crosslinguistic generalizations that the analysis seems to capture. This concerns the fact that predicate and functional items, as distinct from arguments, of nominalized complex constructions seem to cluster across languages. Chomsky (1970), for instance, observes the following contrast for (American) English:

(40) a. He looks the information up.

b. He looks up the information.

(41) a. * The looking of the information up (is difficult).

b. The looking up of the information (is difficult).

Hoekstra (1986) observes a similar contrast for Dutch:

(42) a. Hij zoekt de informatie op.

he looks the information up.

b. ...dat hij de informatie op zoekt.

that he the information up looks.

'...that he looks up the information.'

(43) a. * Het zoeken van de informatie op (is moeilijk).

the looking of the information up (is difficult).

b. Het op zoeken van de informatie (is moeilijk).

the up looking of the information (is difficult).

Just as in Dagaare where the predicate verbal items cluster in a nominalization, in both English and Dutch, as illustrated in (42) and (43), the predicate verbal items 'look'/'looking' and 'up' for English and 'zoekt'/'zoeken' and 'op' for Dutch do not have to cluster in the non-nominalized constructions but must cluster in the nominalized versions for the construction to be grammatical in each language. These therefore seem to be quite relevant cross-linguistic evidence in support of the Dagaare analysis we have presented in the paper. 


\section{Summary and Conclusion}

This paper has presented a discussion of the syntax of a rare kind of complex predicate construction, the Serial Verb Nominalization (SVN) in Dagaare, a language spoken in West Africa. Following a presentation of the relevant facts of the Dagaare NP and SVNs, we have proposed a syntactic representation of SVNs in the DP hypothesis, in the spirit of Bodomo and Oostendorp (1993), along with some LFG-type functional structures of these nominalized complex predicate constructions. Basically, SVNs are VPs headed by a NomP functional projection. The construction was analyzed as a nominalized complex predicate, given the fact that verbs tend to form a complex unit in various syntactic operations.

Given all these findings, we may therefore conclude that cross-linguistically, both nominal(ized) constructions and their verbal counterparts obtain from the same minimal configurations. The only difference between them is that a functional projection, NomP which is nominal in nature, influences the construction and cancels out some inherently verbal categories, such as tense and aspect, from the configuration. 


\section{Notes}

${ }^{1}$ I will like to express my gratitude to various people whose comments and views have helped bring the paper to its present form. I began discussing the rare case of the interaction between serial verbs and nominalization with Marc van Oostendorp way back in 1993, which resulted in a conference paper. Many of the ideas in this paper were first developed then, and have been reshaped and refined in this paper. I am very grateful to Marc for being a good friend and a competent co-investigator of the structure of Dagaare. Finally, I thank colleagues and students at the Department of Linguistics, University of Hong Kong, especially Dr. K. K. Luke, Mr. Owen Nancarrow, Dr. Zhang Wei, and Dr. Steve Matthews for various comments and ideas about this paper at Departmental Seminars. I thank Sophia Lee, Olivia Lam, and Natalie Yu for proofreading and formatting a camera-ready copy of this paper. Needless to say, I am solely responsible for all errors of analysis and presentation in the paper.

${ }^{2}$ The following are among abbreviations that have been used throughout the paper for interlinear translations. Other abbreviations not listed here have been explained in situ:

$1 . \mathrm{SG}=$ First person singular pronoun; $3 . \mathrm{SG}=$ Third person singular pronoun; $\mathrm{COMP}=$ Complementizer DEF $=$ Definite article $;$ DEM $=$ Demonstrative item $;$ DET $=$ Determiner; $\mathrm{EMPH}=$ Emphatic marker; FOC $=$ Focus; FUT $=$ Future tense marker; IMP $=$ Imperfective aspect; INTENS = Intensifier; LOC $=$ Locative marker; $\mathrm{NEG}=$ Negative marker; NOM = Nominative case marker; OBJ $=$ Object PART $=$ Particle PAST $=$ Past tense marker; PERF $=$ Perfective aspect $;$ PL $=$ Plural SG $=$ Singular SUBJ $=$ Subject. 
${ }^{3}$ My attention has been drawn to what seems to be a difference between Dagaare and English NPs with regards to the initial definite article. As can be observed in (4) and (5), the initial definite article, $\grave{a}$, in an NP belongs to the main NP but NOT to a possessor when one is present. In English it would belong to the possessor, e.g. the boy's book. As would be seen later on, however, in nominalized verbal constructions in Dagaare, the initial definite article becomes a constituent of the possessor.

${ }^{4}$ Also not all the adjectives in (10b) are represented in (11b). Indeed (11b), as analyzed in Bodomo and Oostendorp (1993), is more like a GB underlying structure (rather than a C-structure).

${ }^{5}$ There is an interdependence between the $\mathrm{D}$ ámè and the Q áyì and, ultimately, between these and the NP within which they occur. The noun, frrrè 'berry' belongs to a class of non humans in the language. If it were a human class of nouns e.g. nóbj 'people', the phrase would have been à nóbó bámì báyî, instead of à j̀rré ámè áyì.

${ }^{6}$ Regarding the representation of A's as heads in (11b), my attention has been drawn to the idea that in most DP analyses As are represented as complements and not as heads. I would like to believe, however, that the Dagaare data seem to justify the representation of As as heads. In any case, some studies treat adjectives as heads [of AGR] in a French construction like la fille intelligente 'the intelligent girl'. 
${ }^{7}$ There are other nominalization processes such as the formation of agentive nouns with the suffix -ráá (or any liquid and/or a $\mathrm{V}$ related to the $\mathrm{V}$ of the stem) 'doer' put on the imperfective form of the verb (with various vowel and tone changes) e.g.

kó 'farm' $\rightarrow$ kúórò 'farming' $\rightarrow$ kú óráá 'farmer';

yó 'roam' $\rightarrow$ yúórò 'roaming, roving' $\rightarrow$ yúóráá 'roamer/rover, tourist';

$z o ̀$ 'run' $\rightarrow$ zòró 'nunning' $\rightarrow$ zó ró 'runner, athlete'.

Dakubu (1996) also reports that the related language, Gurune, nominalizes verbs by giving the verb roots nominal suffixes.

${ }^{8}$ In previous works, (e.g. Bodomo 1993, 1997, 1998), I have analyzed serial verbs as complex predicates. A complex predicate is, broadly speaking, a single clausal construction in which two or more words/predicates act as a single predicate in terms of certain grammatical information processing e.g. sharing subject and object functions. In these nominalized serial verbal constructions the nominalized verbal predicates share subjects and objects, among other issues.

${ }^{9} \mathrm{I}$ am grateful to an anonymous reviewer for suggesting this approach to better document the facts of this rare type of construction.

${ }^{10}$ In this framework, it is in the f-structure that grammatical functions, such as Subject, Object, etc. are stated. They are not defined in terms of phrase structure configurations. 
These grammatical functions are thus hardly reducible to phrase structure configurations which mostly vary from language to language.

${ }^{11}$ The mechanisms of complex predicates formation within LFG analyses constitute a topic of much discussion. This is indeed the subject of a separate paper and it is not the intention to address this issue at full length. It has, however, been variously treated as a case of predicate composition (e.g. Alsina 1997, Butt 1997), information spreading (Andrews and Manning 1999), or predicate integration (Bodomo 1997, 2003). In most of these analyses the argument structures of predicates that together form a single event are composed or integrated to act as a single but complex predicate argument structure:

zò <Agent/Theme>, gàà <Agent/Theme>, dì <Agent, Patient>

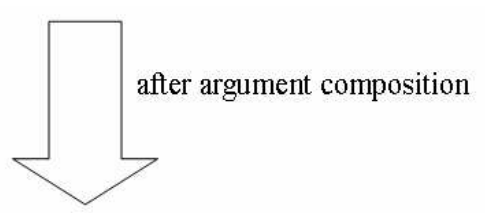

zò-gà̀a-dì <Agent/Theme, Patient>

The monadic verbs $z \grave{o}$ 'run' and g àà 'go' each have a theme (or what some might term an agent) argument, while the dyadic verb $d \hat{\imath}$ 'eat' has an agent and a patient argument. All these three verbs together express the single event of 'move-fast-eat shea fruits'. Their arguments compose and what we now have is a complex PRED zò-gàà-dì in the language. 
This complex verbal predicate then undergoes nominalization, zò-gàà-díú, and thus gets detransitivized.

${ }^{12}$ An alternative analysis of the function involved here as a POSSESSIVE (POSS) rather than SUBJECT has been suggested by an anonymous reviewer, the reasoning here being that English nominalized verbal constructions like 'Mary's frequently visiting Fred' has the following c- and $\mathrm{f}$-structures showing a POSS in the f-structure, as analysed in Bresnan (2001:292-295).

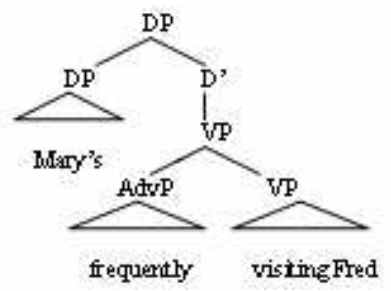

$$
\begin{array}{ll}
\text { PRED } & \text { 'visiting-of }<\text { ( } \uparrow \text { POSS })> \\
\text { POSS } & {[\text { PRED NAMED-Mary'] }} \\
\text { ADJ } & \text { ['frequently'] }
\end{array}
$$

While this is a possibility, I will like to draw attention to the fact that even then there is a lexical rule, The Possessor Subject of Gerundive Verbs (Bresnan 2001:294), which identifies the gerundive SUBJ function with POSS as follows:

$$
\mathrm{V}(\text { gerundive })=>(\uparrow \text { POSS })=(\uparrow \text { SUBJ })
$$

${ }^{13}$ The passive alternation is rare in the language but this nominalization triggers this kind of alternation whereby the object is found in a subject position. 


\section{References}

ABNEY, S. 1987. The English Noun Phrase in its Nominal Aspect. Doctoral dissertation. Massachusetts Institute of Technology. MA, USA.

ALSINA, A. 1997. Causatives in Bantu and Romance. In Alsina, A., J. Bresnan and P. Sells (eds). Complex Predicates. Stanford, CA.: CSLI Publications, 203-246.

ANDREWS, D. AND D. MANNING. 1999. Complex Predicates and Information Spreading in LFG. Stanford, CA.: CSLI Publications.

ANGKAARABA, J. 1980. The nominal phrase in Dagaari. Long Essay. Department of Linguistics, University of Ghana, Legon. Accra, Ghana.

BAKER, M. 1989. Object sharing and projection in serial verb constructions. Linguistic Inquiry 20, 513-553.

BENDOR-SAMUEL, J. T. 1971. Niger - Congo, Gur. In T. Sebeok (ed). Current trends in Linguistics. The Hague: Mouton.

BODOMO, A. B. 1993. Complex predicates and event structure: an integrated analysis of serial verb constructions in the Mabia languages of West Africa. Working Papers in Linguistics 20. Department of Linguistics, University of Trondheim. Trondheim, Norway.

BODOMO, A. B. 1997. Paths and pathfinders: exploring the syntax and semantics of complex verbal predicates in Dagaare and other languages, Doctoral dissertation. The Norwegian University of Science and Technology. Trondheim, Norway.

BODOMO, A. B. 1998. Serial verbs as complex predicates in Dagaare and Akan. In I. Maddieson and T. Hinnebusch (eds). Trends in African Linguistics Vol. 2, Language History and Linguistics Description in Africa. Trenton, NJ.: Africa World Press, 195204.

BODOMO, A. B. 2003. The syntax and semantics of causative complex predicates in French. Paper presented at the Departmental Seminar, Department of Linguistics, University of Hong Kong. Hong Kong.

BODOMO, A. B. AND M. VAN OOSTENDORP. 1993. Serial verb nominalisation in Dagaare. Paper presented at the 24th Annual Conference on African Linguistics. Columbus, $\mathrm{OH}$, USA.

BRESNAN, J. 2001. Lexical-Functional Syntax. Oxford: Blackwell. 
BUTT, M. 1997. Complex predicates in Urdu. In Alsina, A., Joan Bresnan \& Peter Sells. Complex Predicates, 107-150. Stanford, CA.: CSLI Publications.

CHOMSKY, N. 1970. Remarks on nominalization. In R. A. Jacobs and P. S. Rosenbaum (eds). English Transformational Grammar. Waltham, MA.: Blaisdell, 184-221.

DAKUBU, M. E. K. 1996. A grammar of Grunne. Corrected Trial Edition. Language Centre, University of Ghana, Legon. Accra, Ghana.

DALRYMPLE, M. 2001. Lexical Functional Grammar. Syntax and Semantics, vol. 23. New York, NY.: Academic Press.

FALK, Y. N. 2001. Lexical-Functional Grammar: An Introduction to Parallel ConstraintBased Syntax. Stanford, CA.: CSLI Publications.

HELLAN, L. 1986. The headedness of the NP in Norwegian. In P. Muysken and H. van Riemsdijk (eds). Features and projections. Dordrecht: Foris Publications.

HOEKSTRA, T. 1986. Deverbalization and inheritance. Linguistics, 24: 549-584.

JACKENDOFF, R. 1997. The Architecture of the Language Faculty. Cambridge, MA: MIT Press.

OSAM, E. 1994. Aspects of Akan Grammar - A Functional Perspective. Doctoral dissertation. University of Oregon. OR, USA.

SADOCK, J. 1991. Autolexical Syntax. Chicago, IL.: University of Chicago Press.

Author's name: $\quad$ Adams B. Bodomo

Affiliation: $\quad$ Department of Linguistics

University of Hong Kong

Postal Address: $\quad$ Department of Linguistics

University of Hong Kong

Pokfulam Road

Hong Kong

Email: $\quad$ abbodomo@hku.hk

Website: $\quad$ http://www.hku.hk/linguist/staff/ab.html 